\title{
IDENTIFICATION OF INTERFLOW PATHWAYS AND POTENTIAL WETLAND SITES IN THE KELLY HAYFIELDS
}

\author{
CLAYTON B. MARLOW $\uparrow$ DUSTIN ANDERSON \\ ANIMAL AND RANGE SCIENCES $\uparrow$ MONTANA STATE UNIVERSITY $\uparrow$ BOZEMAN
}

\begin{abstract}
$\uparrow \quad$ ABSTRACT
In support of Grand Teton National Park Service plans to restore the Kelly Hayfields to prehomesteading conditions an inventory of soils and associated vegetation was conducted over a two year period, 2010 and 2011. Measurements from 37 soil pits and 19 associated vegetation descriptions revealed little evidence for the presence of riparian wetlands anywhere within the historic hayfields. The exception was a small area near the north eastern end of Blacktail Butte. Faint soil redoximorphic features associated with about 5\% wetland indicator plant cover implies the existence of riparian wetlands at the time of homesteading. Differences in soil texture across the hayfields indicates that a mosaic of herbaceous and mountain big sagebrush/grass communities existed when agricultural conversion began. Based on these results Grand Teton National Park's restoration efforts should focus on reestablishment of sagebrush-grassland complexes.
\end{abstract}

\section{$\downarrow \quad$ INTRODUCTION}

As part of the 2007 Bison-Elk Management Plan Grand Teton National Park (GTNP) undertook a study of the western section of the Antelope Flats area (Kelly Hayfields) to prioritize areas for future restoration efforts. The central focus of the restoration inventory was identification of wetlands that may have existed prior to agricultural conversion and whether or not the hydrologic/soil factors that had been responsible for their creation and maintenance were still in place. Knowing the extent and location of historic wetlands would help Park
Service Specialists decide if wetland recovery would be supported by the current hydrologic patterns, or if extensive wetland reclamation should be part of the Park's restoration plan for the Antelope Flats area. The study began in the spring of 2010 and continued through the fall of 2011. During the study 28 soil pits were excavated and 9 bore holes drilled (mechanical Giddings probe) seeking evidence for a persistent groundwater table which would have supported historic wetlands in the Kelly Hayfield. Following the soil survey an extensive vegetation inventory was conducted in late summer 2011 to identify the present vegetation community structure and diversity associated with the soil pits and bore holes.

\section{$\uparrow \quad$ STUDY AREA}

Prior to the establishment of Grand Teton National Park (GTNP), intensive homesteading and cultivation turned nearly 4,000 acres of native shrub steppe occupying the Antelope Flat area between Blacktail Butte and the Gros Ventre River into nonnative irrigated hayfields and pasture. Further impacts to natural processes were created as a network of irrigation ditches were dug across homestead land to distribute water diverted from nearby surface streams to boost hayfield and pastureland production.

The study area was located near Moose, Wyoming north of Jackson Hole, Wyoming. The Kelly Hayfields are bound by the Gros Ventre road to the south and Antelope Flats road to the north (elevation 6528 feet above sea level) (Figure 1). The 
landform setting of the Antelope Flats area (Kelly Hayfields) is a shallow-gradient alluvial fan sloping west-southwest from the toe of the Gros Ventre Mountain range towards Blacktail Butte. The depositional setting is a relatively level plain composed of loess and alluvial sediments deposited over glacial outwash.

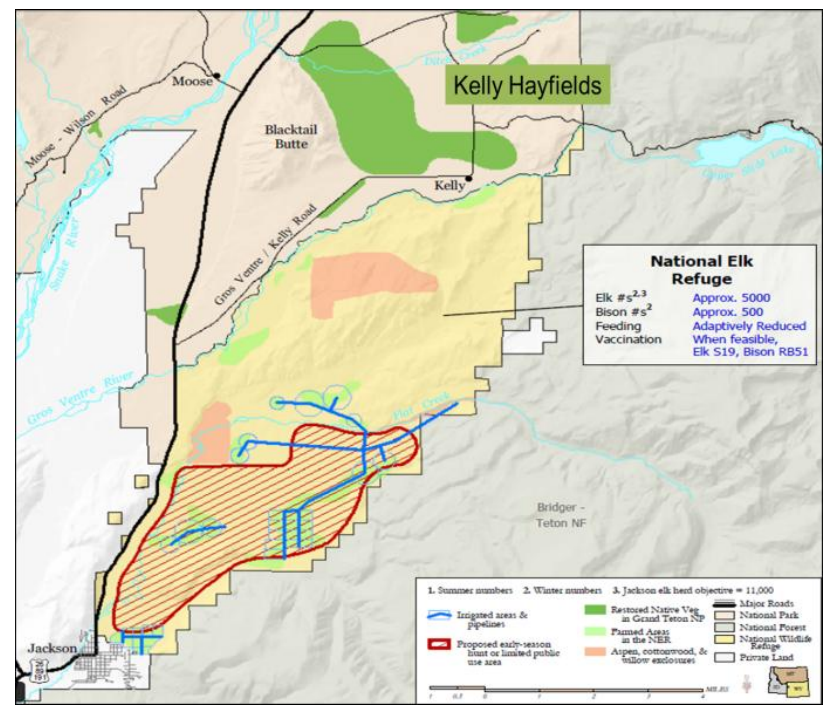

Figure 1. Generalized location of the Kelly hayfields within Antelope Flats, Grand Teton National Park, Moose, WY.

\section{$\uparrow \quad$ METHODS}

Twenty-eight soil pits were excavated to completion depths of $\sim 30-115 \mathrm{~cm}$ (Figure 2). The NRCS Field Book for describing and sampling soils, version 2.0 was employed to sample, code and describe the soil samples. Soils were characterized by: color using the Munsell color guide (hue, value, and chroma), structure (visually following NRCS field book) and application of dilute hydrochloric acid $(\mathrm{HCl})$ to identify calcareous matrix cementation in the field. The extent and rate of effervescence created by application of the acid indicates the amount of carbonate and its chemical and physical nature. The samples were collected in situ labeled and transported to Montana State University for laboratory analysis. Particle-size was characterized by the use of mechanical hydrometer analysis (Gee and Bauder 1986), total carbon was characterized by loss on ignition testing (Heri et al. 1999), and $\mathrm{pH}$ was recorded using a Hanna HI 98129 multi-parameter meter. The soil pits were excavated in the Tineman and Leavitt soil series (Scoeneberyer 2002). Vegetation communities within the Kelly hayfields and surrounding shrublands are representative of the Timothy-Kentucky Bluegrass-Smooth Brome, Mountain Big Sagebrush, Mountain Snowberry/Needleandthread shrubland, Mountain Big Sagebrush - Mountain Snowberry/Idaho fescue shrubland and Mountain Big Sagebrush - Mountain Snowberry-Bluebunch wheatgrass shrubland plant alliances (Cogan et al., 2005).

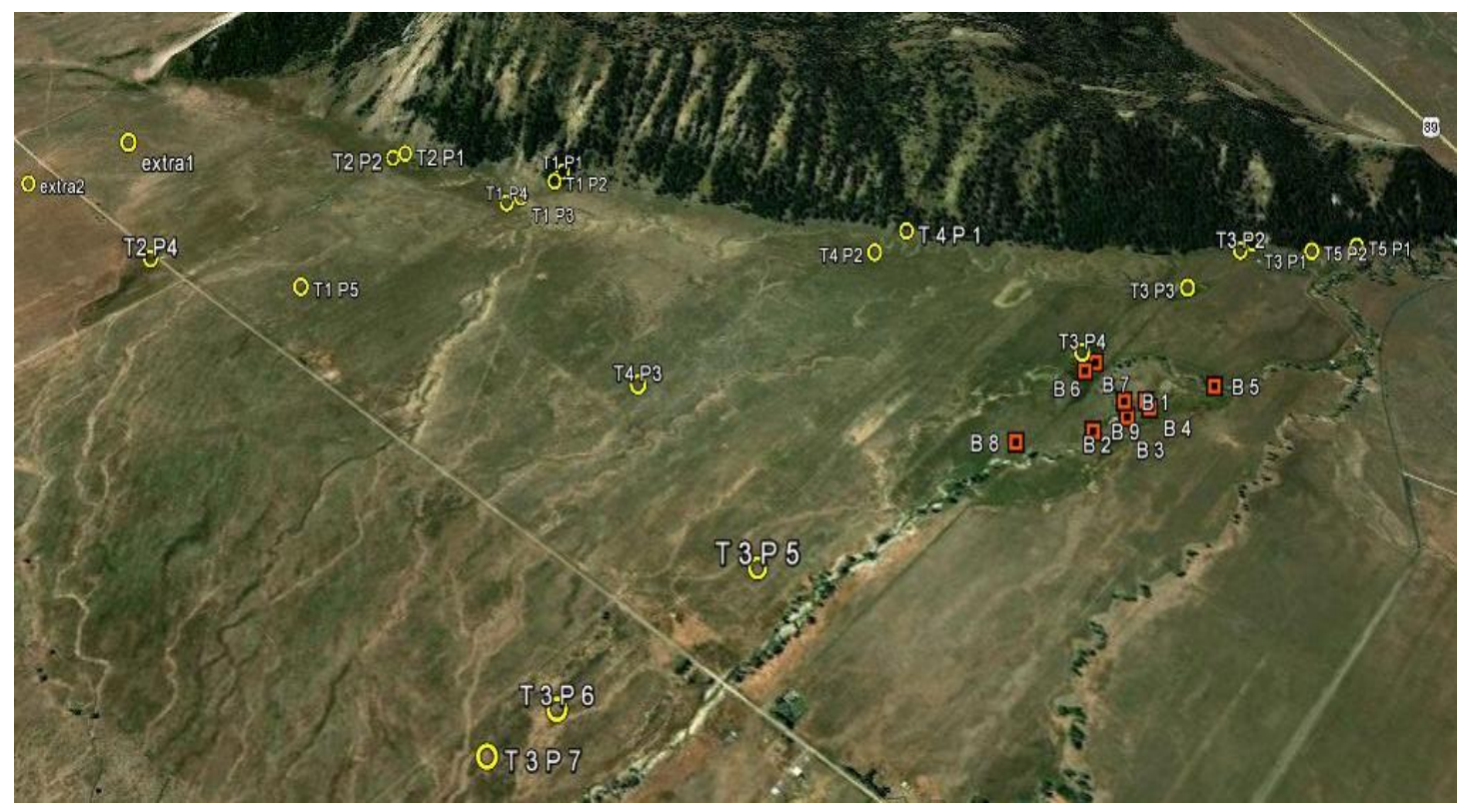

Figure 2. An aerial photo of the Kelly Hayfields on the eastern side of Blacktail Butte. Soil pits are denoted by yellow circles and bore holes by orange squares. 


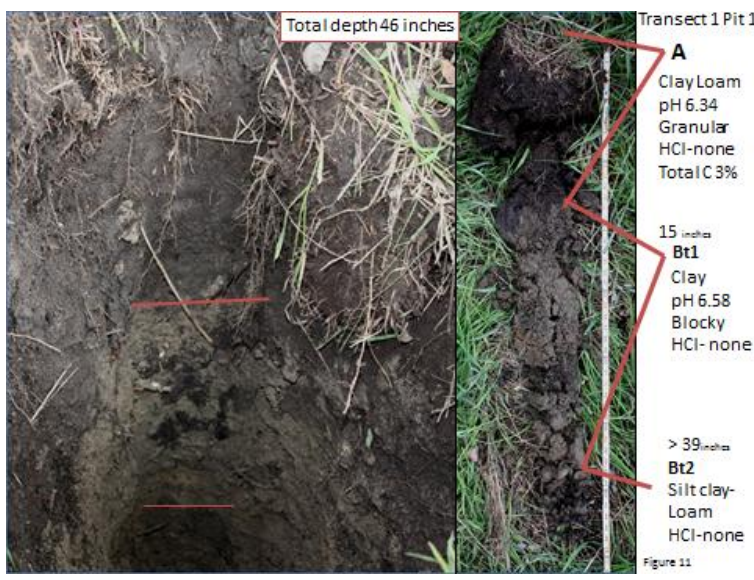

Figure 3. A soil pit and profile descriptions representative of the 37 pits and bore holes sampled within the Kelly hayfields during 2010.

\section{Description of the Vegetation Community}

Species composition of the vegetation complexes associated with 19 of the 37 soil pits was determined through foliar cover measurements made by following the Daubenmire technique (Daubenmire 1968). Four sampling lines were anchored on each soil pit location and then oriented in north, south, east, west directions. Foliar cover (by species), bare ground and litter were estimated in three $20 \times 50 \mathrm{~cm}$ quadrat frames spaced at 5,25 and $50 \mathrm{~m}$ intervals along two randomly selected lines and then repeated at 5 and $25 \mathrm{~m}$ intervals along the two remaining sampling lines. This approach produced a total of 10 quadrats per soil pit. Cover measures were summarized for each soil pit and then analyzed for similarity with cluster analysis (STATISTICA Academic 2011). Vegetation within similar groups was further categorized as to obligate (OBL), facultative wetland (FACW) and facultative (FAC) wetland indicator status (Lesica and Husby 2001).

\section{$\uparrow \quad$ RESUlTS}

\section{Hydric soil analysis}

Soil pits were excavated and the Munsell color guide and NRCS Field Guide were employed to describe soil structure and determine the presence or absence of redoxomorphic diagenesis, gleying or other chemical indicators of a persistent groundwater table. Gleying and redoximorphic features would indicate previous patterns of water flux or soil pore saturation for prolonged periods. Field observations found limited evidence of diagenesis or other soil chemical reactions in most of the soil pits (Figure 3).
Weak chemical reactions were apparent around rootholes in pits proximal to the toe of Blacktail Butte (T1P1, T1P2,T2P1, T2P2) with pits revealing the most developed redox-features located on the northern-most end of Blacktail Butte proximal to Ditch Creek (T5P1, T5P2, T3P1 and T3P2). Soil features noted in all other pits were non-supportive of a paleo-wetland or riparian relics.

\section{Particle-size Analysis}

Results of laboratory particle-size analysis conducted at Montana State University indicate that much of the Kelly Hayfield soils are composed of clay with lenses of loams to sandy loams, likely a function of proximity to the alluvial fan and paleoclimatic events producing vacillating precipitation or snowmelt discharge outflow.

Pit and bore holes excavation reached depths of $\sim 1$ meter (hand excavated pits) to 4 meters (boreholes) below the ground-surface. We observed limited amounts of disseminated clastic material (gravel and rock fragments $>2 \mathrm{~mm}$ ) in the central portions of the hayfields. Clastic material observed were primarily lenticular indicative of pulsating discharge events, again suggestive of paleo-climatic events. With many soil pits lacking any clastic material in the upper $72-\mathrm{cm}$ of soil profile the possibility of fluvial transport is unlikely. This coupled with the high concentration of clays suggest most of the soil material resulted from eolian transport. Also, supportive of eolian transport is the thickness of the clay profile; exceeding 4 meter depths (without any clastic material $>2 \mathrm{~mm}$ ) in many places.

\section{Percent Carbon Analysis}

Sequential loss on ignition (LOI) is widely used as a method of estimating the organic and carbonate content of soils. We employed LOI on samples collected at the Kelly Hayfields. Following laboratory analyses, we recorded a total organic carbon percent range of $2 \%$ to $7 \%$. These values are significantly less than what is specified by the US Army Corps of Engineers for lentic and lotic wetlands (Wetland Delineation Manual 1987).

\section{Vegetation Community Description}

The extensive soil survey of the Kelly hayfield coupled with the vegetation inventory indicates that historically wetlands and riparian areas were restricted to the immediate eastern flank of Blacktail Butte and the topographic restriction on the 
north-end of the butte. Soils developed in alluvium, buried soil profiles and the presence of wetland indicators reinforces the potential existence of historic wetlands at sites T5P1, T5P2, T3P1 and T3P2 (blue oval, Figure 4). Overall site similarity was driven by the amount of smooth brome cover at each site (Table 1).

Table 1. Vegetation composition of similarity groups identified in Figure 3. Individual species composing greater than $1 \%$ of the plant community are listed. $\mathrm{NA}=$ introduced species, INV = invasive non-native species, $\mathrm{FAC}=$ facultative wetland indicator, $\mathrm{OBL}=$ obligate wetland indicator.

\begin{tabular}{|c|c|c|c|}
\hline Cluster & Species & $\begin{array}{l}\text { Foliar } \\
\text { Cover } \\
(\%)\end{array}$ & Wetland Status \\
\hline & Bromus inermis & 9 & Introduced \\
\hline & Poa pratensis & 4.1 & Introduced \\
\hline & $\begin{array}{l}\text { Artemisia tridentata } \\
\text { wyomingensis }\end{array}$ & 3.1 & Upland \\
\hline & $\begin{array}{l}\text { Geranium } \\
\text { richardsonii }\end{array}$ & 1.9 & Facultative \\
\hline \multirow[t]{7}{*}{ Blue } & $\begin{array}{l}\text { Eriogonum } \\
\text { umbellatum }\end{array}$ & 1.7 & Upland \\
\hline & $\begin{array}{l}\text { Symphyotrichum } \\
\text { campestre }\end{array}$ & 1.6 & Facultative \\
\hline & $\begin{array}{l}\text { Taraxacum } \\
\text { officinale }\end{array}$ & 1.6 & Introduced \\
\hline & Cerastium arvense & 1.4 & Upland \\
\hline & Potentilla gracilis & 1.1 & Facultative \\
\hline & Bromus inermis & 33.3 & Introduced \\
\hline & Poa pratensis & 4.7 & Introduced \\
\hline \multirow[t]{4}{*}{ Red } & Cirsium arvense & 2.4 & Invasive \\
\hline & $\begin{array}{l}\text { Taraxacum } \\
\text { officinale }\end{array}$ & 1.1 & Invasive \\
\hline & Bromus inermis & 26 & Introduced \\
\hline & $\begin{array}{l}\text { Solidago } \\
\text { missouriensis }\end{array}$ & 4.9 & Upland \\
\hline \multirow[t]{4}{*}{ Orange } & Poa pratensis & 3.9 & Introduced \\
\hline & Cirsium arvense & 3.2 & Invasive \\
\hline & Salix boothii & 3.1 & Obligate \\
\hline & $\begin{array}{l}\text { Symphyotrichum } \\
\text { campestre }\end{array}$ & 2.4 & Facultative \\
\hline
\end{tabular}

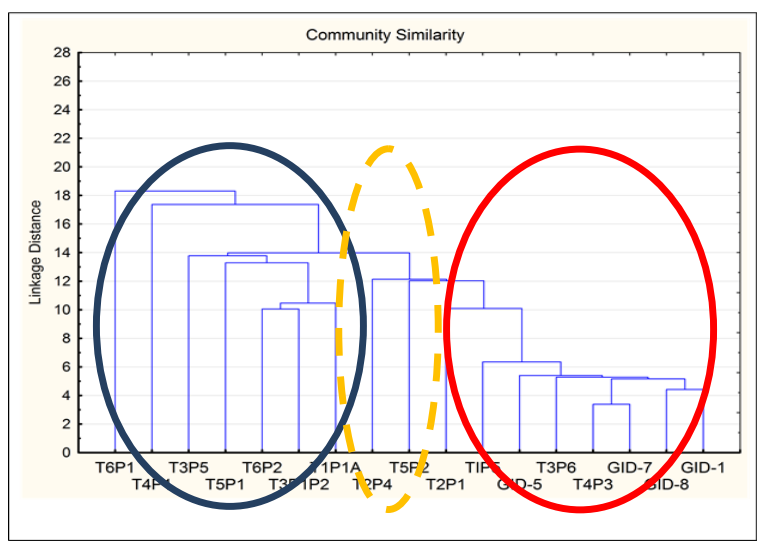

Figure 4. Results of cluster analysis (joining tree) of vegetation associated with select soil pit sites in the Kelly hayfields. Only 2 soil pit sites, T2P4 and T5P2, shared vegetative cover characteristics with both clusters.

In an earlier study at the Elk Ranch the amount of obligate and facultative wetland cover was strongly correlated $(\mathrm{P}=0.001 ; \mathrm{rsq}=0.76)$ to groundwater depths less than $0.8 \mathrm{~m}$. Furthermore, redoximorphic features, principally soil mottles and gleying, were common in the areas of the Elk Ranch with high ground water. In contrast, only 5 of 37 soil pits revealed some form of redoximorphic action in the Kelly hayfields. These features consisted of faint soil mottles and root oxidation associated with a low coverage of wetland vegetation $(<5 \%$ cover). The areas represented by the red oval (Figure 4) had soils with structure and calcic response similar to soils associated with grass and shrub dominated communities. Coupled with the lack of redoximorphic features and wetland indicator species this indicates that the majority of the hayfield area was sagebrush grassland at the time of homesteading. It is likely that there was considerable variation in historic shrub cover across the hayfields because the high clay content recorded at many of the soil pits would have promoted depressional storage for short periods following snowmelt and thunderstorms. This would have produced higher grass and forb cover and less sagebrush at these sites. In direct contrast to these conditions, soil structure and texture at pits T3P6 and T3P7 indicate rapid infiltration and early drying. Sagebrush would dominate in such areas even in close proximity to the stream channel.

\section{MANAGEMENT IMPLICATIONS}

Based on the data collected and analyzed we suggest that the soils and land surface now described as the Kelly Hayfields formed during the rapid retreat of the Bull Lake glaciation. During this retreat a large 
chunk of ice was disconnected and shielded from solar radiation by Blacktail Butte. As this ice melted sediment from the denuded Gros Ventre Range was carried across an alluvial fan and deposited adjacent to the melting ice. A large depression (the Kelly hayfields) was left when the abandoned ice finally melted. This depression was then filled with eolian loess lifted from the Gros Ventre derived fan. In time rangeland vegetation colonized, stabilizing and ultimately developing the mature grassland soil features observed in this study.

The isolated occurrence of soil and wetland vegetative indicators to one small area of the Kelly hayfields substantiates the argument that the majority of the hayfields were mountain big sagebrush shrublands interspersed with grass dominated herbaceous communities. Consequently, we conclude that the ecological potential for most of the Kelly Hayfields is sagebrush grassland. With this information restoration efforts can be focused on reestablishment of native grass and shrub species in the former hayfields. It should be noted that reseeding efforts will be more successful when soil level conditions are addressed in developing seeding mixtures. For example, grass and forb species should be seeded into sites with high clay content and shrubs into sandy and gravelly loam sites. Any riparian rehabilitation efforts should be confined to a $30-50$ $m$ boundary along Ditch Creek and landscapes within the topographic restriction at the north-end of Blacktail Butte.

\section{ACKNOWLEDGMENTS}

In addition to support from the UW-NPS Research Station, this project has received key funding from the Animal and Range Sciences Department, Montana State University. Access and collection permits were facilitated by Dr. Kelly McCloseky, Grand Teton National Park with data collection and analysis help from Neto Garcia and Eric Hester.

\section{$\downarrow$ Literature Cited}

Cogan D, Varga K, Kittel G, McCloskey K, Abendroth D, Gremer J, Bolen C. 2005. USGS-NPS Vegetation Mapping Program. Grand Teton National Park and John D. Rockefeller, Jr. Memorial Parkway Final Project Report. Technical Memorandum 8260-06-02. USDI Bureau of Reclamation Technical Center, Remote Sensing and GIS Group, Denver, CO.

Daubenmire R. Plant Communities. A textbook of plant synecology. New York: Harper and Row; 1968.

Gee GW, Bauder JW.. Particle-size AnalysisMethods of Soil Analysis. In: Klule A, editor. Part 1-Physical and Mineralogical Methods. $2^{\text {nd }}$ edition. Madison (WI): American Society of Agronomy;1986.

Heiri O, Lotter AF, Lemcke G. 2001. Loss on ignation as a method for estimating organic and carbonate content in sediments: reproducibility and comparability of results. Journal of Paleolimnolgy 25:101-110.

Lesica P, Husby P. Field Guide to Montana's Wetland Vascular Plants. Helena (MT): Montana Wetland Trust; 2001.

Schoeneberger PJ, Wysocki DA, Benham EC, Broderson WD. Field book for describing and sampling soils, Version 2.0. Lincoln, (NE): Natural Resources Conservation Service, National Soil Survey Center; 2002.

Statistica. Academe. Ver. 1. StatSoft, Inc. Tulsa, OK 